\title{
ANALIZA GEOGRAFSKIH DEJAVNIKOV BOJIŠČA 14. ARMADE V 12. SOŠKI OFENZIVI
}

\author{
ANALYSIS OF GEOGRAPHICAL FACTORS \\ OF THE $14^{\text {TH }}$ ARMY BATTLEFIELD IN \\ THE TWELFTH ISONZO OFFENSIVE
}

Povzetek Pri razčlenjevanju zgodovinskega primera vojaške izrabe prostora in uporabe taktičnih postopkov pri doseganju strateških ciljev ugotavljamo prepletenost dejavnikov in posameznih dogodkov v povezavi z rezultati izvedenih vojaških aktivnosti. S presojo zgodovinskih okoliščin vojaških ravnanj interpretiramo vzroke in posledice ter izpeljujemo načela delovanja vojaških enot; tako odkrivamo temeljne resnice in splošna pravila oboroženega boja. Vrednotenje učinkov geografskih dejavnikov na obvladovanje in rabo nekega geografskega območja z vojaškimi tehnologijami po uveljavljenih pravilih delovanja vojaških enot ima osrednjo vlogo pri proučevanju součinkovanja prostora in vojaške sile.

Izraba prostora 14. armade v 12. soški ofenzivi je bila zelo spretna glede na takrat še neuveljavljena načela bojevanja. Uporaba vojaške taktike infiltracije posebnih udarnih enot v globino obrambe je temeljila na izrabi učinkov prostora in vremena. Proti ustaljeni obliki izrabe prostora v frontalni taktiki bojevanja je bila uporabljena metoda napada tvegana, a ključna za preboj na Tolminskem mostišču.

V prispevku so opisani vojaškogeografski dejavniki zgornjega in srednjega soškega bojišča ter ocena učinkov terena in vremena na bojno delovanje 14. armade v 12 . soški ofenzivi. V obravnavi zgodovinskega primera spoznamo geografske dejavnike, ki so določali in usmerjali aktivnosti enot v 12. soški ofenzivi.

Ključne besede

Abstract

\section{Geografski dejavniki, operativno okolje, študija primera, 12. soška ofenziva.}

When analysing the historical case of the military use of space and tactical procedures in the achievement of strategic goals, we identify the intertwinement of the features and individual events related to the results of the accomplished military activities. By analysing the historical circumstances surrounding military actions, we interpret the 
causes and consequences and derive the principles of operation of military units. In this way, we discover the fundamental truths and general rules of an armed conflict. The evaluation of the impact of geographical factors on the management and use of a geographical area with the military means of technology following the established military rules of engagement plays the central role in the investigation of mutual effects of space and military force.

The use of space by the $14^{\text {th }}$ Army in the Twelfth Isonzo Offensive was very clever considering the fact that, at the time, the principles of warfare had not yet been in place. The use of military infiltration tactics of special strike units in defence in depth was based on the use of space and weather effects. Used against the well-established use of space in the front warfare tactics, the method of attack which was used was risky, but crucial for the breakthrough at the Tolmin bridgehead.

The article describes the military and geographical factors of the upper and central battlefields of the Isonzo as well as the assessment of terrain and weather impacts on combat operations of the $14^{\text {th }}$ Army in the Twelfth Isonzo Offensive. The study of this historical case reveals the geographical factors, which determined and directed the activities of units in the Twelfth Isonzo Offensive.

\section{Key words Geographical factors, operational environment, case study, the Twelfth Isonzo Offensive.}

Uvod Razumevanje operativnega okolja vojskovanjaje pomembno za načrtovanje aktivnosti in delovanje vojaških enot. Zgodovina vojn v Evropi in po svetu s številnimi primeri bitk potrjuje, da geografski dejavniki bojišča glede na čas opredeljujejo delovanje vojaške sile in vplivajo na njegov izid. Naravne in ustvarjene značilnosti prostora so nosilec moči, ki oblikujejo razmere in utemeljujejo razloge za razvoj dogodkov in njihovih posledic. Kunaver (2000) izrecno poudarja, da vojaške geografije ni mogoče obravnavati brez primerov uporabe in upoštevanja geografskih dejstev in dejavnikov v vojaških operacijah ter trdi, da je študijskih primerov vojaškogeografskih analiz glavnih operativno-taktičnih smeri, ki so v središču pozornosti vojaštva, veliko, a za obrobna območja bistveno manj. Predvsem je malo geografskih obravnav preteklih pomembnih bojevališč na Slovenskem, zato je bila smiselna odločitev za vojaškogeografsko obravnavo bojišča 14. armade v 12. soški ofenzivi. Cilj vojaškogeografske obravnave zgodovinskega dogodka je omogočiti udeležencu učnega procesa v programih poveljniško štabnih šolanj v Centru vojaških šol, da poleg spoznanj, kako so odločitve poveljnikov oziroma vodij in vojaška tehnologija vplivale na razvoj taktik in delovanje vojaških enot, izoblikuje tudi razumevanje, kako geografski prostor in njegovi učinki determinirajo vojaške odločitve, delovanje vojaških enot in celo izid bojevanja.

Zgodovinski del študije oboroženega spopada na Soški fronti v 12. ofenzivi kot študija primera za potrebe poučevanja taktike, ki se izvaja na terenu, je že uveljavljena 
metoda poučevanja v programih vojaškega izobraževanja v Slovenski vojski ${ }^{1}$. Metoda študija primera vojaške operacije zahteva celovito obravnavo dogajanja, umeščenega v pretekla prostor in čas. Poleg predstavitve zgodovinskih dogodkov mora poročati še o strukturi vojaške sile, sistemu vodenja in poveljevanja ter zmogljivosti uporabljenih oborožitvenih in drugih sistemov. V teoretični obravnavi mora študija zgodovinskega primera razložiti načrtovanje, potek boja in uporabo taktičnih načel ter posledic delovanja vojaških enot v okviru tedanjega geografskega prostora in njegovih učinkov.

Namen analize geografskih dejavnikov bojišča 14. armade v 12. soški ofenzivi je oblikovati dodatne podlage za izvedbo študije primera operacije z vidika vojaškega vrednotenja prostora. Po analogiji zgodovinske metode je cilj analize izpeljati razumevanje vplivov geografskih dejavnikov bojišča na načrtovanje, pripravo ter izvajanje vojaške operacije 14. armade v 12. soški ofenzivi.

Vojaškogeografska analiza območja vojaških aktivnosti 14. armade v 12. soški ofenzivi je narejena po metodologiji vojaškogeografskega proučevanja, v okviru katerega se je izvajalo vrednotenje geografskih dejavnikov ter ocenjevanje njihovih vplivov na načrtovanje in bojno delovanje. Ocenjevanje učinkov prostora temelji na informacijah o geografskih značilnostih zgornjega in srednjega soškega bojišča ter upošteva vpliv posameznih dejavnikov bojišča ter njihov združen vpliv na bojevanje ${ }^{2}$.

Izid vojaškogeografske presoje preteklih pomembnih bojevališč rekonstruira predstavo zgodovinske stvarnosti, ki je zaporedje dogodkov, v predstavo vzročno-časovne pojavnosti dogodkov, ki jo sestavlja niz vzrokov in pogojev, ki so omogočili dogodek. Varanneli (2016) govori o procesih, ki v sferi najrazličnejših situacij identificirajo razmere, ki privedejo do vzročnih stanj za posledice. Z analizo stanj prepoznamo vplive v prostoru, ki omogočijo presojo pravilnosti in nepravilnosti izbire ali odločitve.

Vojaškogeografska presoja zgornjega in srednjega soškega bojišča konstruira predstavo zgodovinske stvarnosti delovanja 14. armade v 12. soški ofenzivi. Uporabna je za dopolnitev študije primera in oblikovanje razumevanja vplivov dejavnikov prostora na odločitve ter izvedbo prodora na tolminskem mostišču.

\section{VOJAŠKOGEOGRAFSKA PRESOJA PROSTORA BOJEVANJA V PRIPRAVI ŠTUDIJE ZGODOVINSKEGA PRIMERA BOJEVANJA}

Metoda vojaškogeografske presoje območja vojaškega delovanja omogoča uporabniku razumevanje geografskega prostora, ozemeljsko ločenega od celote, kot realno in celovito prostorsko enoto izvajanja vojaških aktivnosti. Z analizo

\footnotetext{
Vojaški muzej Slovenske vojske za potrebe Centra vojaških šol izvaja študije primerov vojaških aktivnosti na Slovenskem in v okviru teh študijo 12. soške ofenzive z ogledom bojišča.

2 Razumevanje vplivov prostora na bojevanje zahteva precejšnje napore od vojaških poveljnikov in njihovih enot. Poveljniki morajo pri sprejemanju odločitev pravilno oceniti učinke prostora na uporabo enote (Bratun, 2005, str. 28). Združen vpliv geografskih dejavnikov na bojišču se kaže kot funkcija podnebja, oblike površja, hidroloških in biotskih razmer, strukture antropogenih elementov in časa.
} 
geografskih dejavnikov prostorske enote spoznavamo njegovo originalnost, razprostranjenost značilnih pojavov in součinkovanja prvin prostora in s presojo sintetiziramo predstavnost posameznega dela Zemljinega površja, določenega za izvedbo vojaških aktivnosti.

Za enoto vojaškogeografske analize opredelimo operativno okolje delovanja enote. Operativno okolje ni razumljeno le kot teritorij, ampak skupek dejavnikov, ki vplivajo na delovanje vojaških enot. V opredeljenem operativnem okolju analiziramo dinamične procese, zakonitosti dogajanja in stanja ter odnosov v geografskem prostoru od podnebja, lokalnih vremenskih situacij, geologije, reliefa, površinskega pokrova in prostorskega reda do družbenih in kulturnih značilnosti področja operacije (Bratun, 2005).

Smoter izvajanja vojaškogeografske analize operativnega okolja je produkcija kakovostnih informacij o zmogljivosti prostora za delovanje vojaških enot, ki so pomembne za oblikovanja optimalnejšega načrta vojaškega delovanja.

Ocenjevanje vojaških vidikov terena se v enotah Slovenske vojske izvaja po modelu vojaškogeografskega vrednotenja terena $\mathrm{z}$ ocenjevanjem učinkov bojišča na manever in delovanje vojaških enot, kar se izraža v zmogljivosti prostora za bojevanje. Zmogljivost prostora utemeljujemo na podlagi operativno-taktičnih norm, ki temeljijo na zgodovinskih razmerjih učinkovitosti vojaških enot ter izračunu verjetnosti doseganja cilja oziroma zmage na bojišču ob izpolnjevanju optimalnih razmer $\mathrm{v}$ prostoru. Na podlagi zbranih informacij o zmogljivosti prostora za delovanje vojaških enot se določijo optimalne širine in globine delovanja enote v razponu zgodovinskih operativno-taktičnih norm.

Tehnika oblikovanja študije zgodovinskega primera bojevanja se izvaja v več zaporednih stopnjah. Začne se s študijem zbranega gradiva, ki mora imeti verodostojno pričevalno vrednost in nadaljuje s sistematičnim razčlenjevanjem zgodovinskih dogodkov. Sledi ji faza analize vojaških zmogljivosti in identificiranje lokacij točk osredotočanja vojaških aktivnosti in manevrov enot. Ugotovitve nato integriramo s spoznanji, izkušnjami in znanjem, ki izhajajo iz sodobnih teorij in aktualnih načel bojevanja. Takšen model oblikovanja primera zgodovinske študije bojevanja zagotavlja ustrezne parametre za kvalitativno večparametrsko analizo zgodovinskega dogodka. Namen tako pripravljene študije primera je analiza bitke ali spopada na terenu, kjer udeleženec podoživi boj in z lastnim pogledom izoblikuje spoznanja (Conduct of the Staff Ride).

Za oblikovanje študij primerov je značilno, da s kvalitativno metodo raziskovanja pojavov preučujemo dogodke in subjektivna doživetja ter ugotavljamo pomen, ki se ga pripisuje posameznim dogodkom. Metoda kvalitativnega raziskovanja zajema preučevanje značilnosti, dogajanja, opis procesa odkrivanja teh značilnosti in njegovo analizo (Mesec, 1998). 
Rezultat uporabe kvalitativne metode $\mathrm{v}$ pripravi študije primera je interpretacija zmogljivosti okolja skozi oceno moči vpliva posameznih dejavnikov na posamezni dogodek ali aktivnost (bitke/spopada) oziroma na soustvarjanje okoliščin izida aktivnosti. Pri tem upoštevamo celoten spekter učinkov prostorskih struktur in uporabljenih vojaških zmogljivosti.

Izražena dodana vrednost procesa izvedbe študije zgodovinskega primera bojevanja je, da dobimo priložnost za ponovno oceno aktivnosti, politike in procesa odločanja ter vodenja aktivnosti v luči prejetih informacij in spoznanj (Starman, 2013).

\section{VOJAŠKOGEOGRAFSKA PRESOJA OBMOČJA BOJIŠČA 14. ARMADE V 12. SOŠKI OFENZIVI}

V poglavju so predstavljeni osnovni elementi vojaškogeografske presoje območja delovanja 14. armade v 12. soški ofenzivi (slika 3, str. 98). Predstavitev zajema orientacijo in opis krajinskih značilnosti prostora ter poudarke iz presoje geografskih dejavnikov, ki pojasnijo nekatere okoliščine in razmere kot posledico učinkov bojišča na bojevanje.

\subsection{Bojišče 14. armade $\mathbf{v}$ 12. soški ofenzivi}

Območje delovanja 14. armade je umeščeno na severni del soškega bojišča, v prostor zgornjega in srednjega toka reke Soče. Glede na njegovo umeščenost v prostor Posočja ga delimo na zgornjesoško in srednjesoško bojišče.

Območje vojaškogeografske analize obsega zemljišče razporeda enot in smeri napada korpusov po načrtu delovanja 14. armade v 12. soški ofenzivi³. Meje njenega operativnega območja delovanja so potekale po frontni črti od Rombona do Gorenjega Loga v dolini Soče.

I. avstro-ogrski korpus je bil razporejen na frontni črti od Rombona do Batognice (2153 n. m. v. JV od KRN - izključno), razporeditev treh korpusov 14. armade pa je bila naslednja:

- III. bavarski korpus od Batognice do Tolmina,

- LI. nemški korpus od Modrejce do Sela pri Volčah (izključno),

- XV. korpusa od Sela pri Volčah (vključno) do Gorenjega loga (Galič, Marušič, 2005, 177).

\subsection{Vojaškotaktične smeri delovanja 14. armade}

Skladno z operativnim načrtom 14. armade je I. avstro-ogrski korpus imel nalogo izvesti preboj frontne črte v Bovški kotlini ter prodreti po dolini v smeri toka reke

\footnotetext{
14. armada in I. avstro-ogrski korpus sta bila podrejena sicer poveljstvu jugozahodne fronte (poveljnik nadvojvoda Evgen), a je bil I. avstro-ogrski korpus za izvedbo ofenzive formalno podrejen 14. armadi in ni imel svobode delovanja (Galič, Marušič, 2005, 176).
} 
Soče skozi ožino prevoja pri Žagi in v smeri Trnovega; pozneje prodirati čez hribovje in Stol v Rezijsko dolino, do Drežnice in Kobarida prek Vršiča in sedla Zaprikaj. Po osvojitvi Breginja in Robiča naj bi se nadaljeval prodor po dolini Rezije in Učje do Humina (it. Gemone) in Osoppa. Načrt manevra I. avstro-ogrskega korpusa je predvidel, da bi 22. strelska divizija z izhodiščnih položajev v dolini severovzhodno od Ravelnika prebila italijansko obrambo vzdolž celotne kotline pod italijanskimi položaji na pobočju Kanina in Polovnika, zasedla Žago in osvojila Stol. Divizija Edelweiss naj bi s položajev vzhodnega pobočja Rombona spremljala preboj 22. divizije in pregnala Italijane s Čukle ter nato zasedla dolino Učje ter osvojila vzpetine nad njo. 55. divizija naj bi s položajev na Javorščku napadla in zasedla italijanski obrambni črti na Polovniku (slika 1, str. 79).

Bojišče 14. armade v zgornjem toku reke Soče obsega Bovško kotlino in v njo stekajoči se dolini, s pobočjem Svinjaka, ki ju razdvaja (dolino Koritnice in dolino Soče, ki priteče iz njenega povirja); gorske masive, ki obdajajo kotlino: Rombon, Krnica in Kanin na zahodu, Golobar in Javoršček na vzhodu ter Polovnik na jugu; razširjeno prodno dolino Soče od Loga Čezsoškega čez Žago do Srpenice z dolino Učje in vzpetine nad njo, Polovnik ter Stol in sotesko ter prodorno dolino reke Soče med njima (od rudnika krede pri Srpenici do Kobarida). Operativni načrt je korpusom 14. armade, razporejenim na frontni črti od Batognice do Gorenjega loga, določal naslednje delovanje:

- III. bavarski korpus:

a) preboj frontne črte in zasedba pomembnega položaja na Kolovratu, na gradu kota 1114, čiščenje Kolovrata, zasedba Matajurja in zavarovanje doline zgornje Nadiže,

b) prodor po obeh smereh proti toku skozi dolino Soče (z zasedbo Krna in južnih delov) do Kobarida in čez Robič prodirati po dolini Nadiže proti Čedadu;

- LI. nemški korpus: preboj frontne črte in osvojitev masiva Ježe (949) in nato prodor čez Sv. Martin proti Čedadu;

- XV. korpus: prodor in osvojitev vrhov južno od Ježe (Varda-Čepovan-Grad) in napredovati čez Staro goro (Castelmonte) proti Čedadu (Galič, Marušič, 2005, 178).

Operativno območje delovanja enot 14. armade se začne na $17 \mathrm{~km}$ dolgi frontni (izhodiščni) črti, ki se začne na desnem bregu reke Soče nad Kobaridom, od Batognice naprej teče po Krnskem pogorju in po robu Julijskih Alp proti jugu ter se pri Doljah spusti v dolino Soče. Nato teče ob Kozlovem robu do Tolmina, kjer prečka Sočo in po levem bregu zahodno prečka Bučenico in zaobide Kozaršče. Naprej teče prek Selskega vrha do Sel, kjer preide na desni breg reke Soče in se zaključi pri Gorenjem logu pod Malim vrhom (slika 2, str. 79).

Prostor bojišča sega od frontne črte čez celotni severni del srednje doline Soče in naprej prek Kolovrata in po dolini Nadiže v Beneško Slovenijo do Čedada. Prva faza delovanja enot je bila načrtovana do globine tretje obrambne črte italijanskih sil (cilj 1 na globini od 3 do $6 \mathrm{~km}$ ) in $\mathrm{v}$ drugi fazi delovanje $\mathrm{v}$ zaledju italijanskih enot (cilj 2 na globini $12 \mathrm{~km}$ in več). 


\subsection{Geografska orientacija bojišča 14. armade na porečju Soče}

Porečje Soče zavzema zahodni del Slovenije in je razdeljeno na spodnje, srednje in zgornje območje ter povirje reke Soče ${ }^{4}$. Prostor bojišča 14. armade obsega del srednjega in zgornjega območja reke (slika 4a in 4b, str. 99).

Območje srednje Soče se začenja nad goriško ravnino in obsega prostor prodorne doline reke Soče s prečnim profilom črke V od Solkana do Sela pri Volčah (Kanalsko). Dolina je utesnjena med Banjšice na vzhodu in rob Goriških brd ter Kambreško na zahodu, ponekod ima naplavinske ravnice in se pri Kanalu, Desklah in Avčah nekoliko razširi. Za prodorno dolino od Sela pri Volčah se začne tako imenovano Tolminsko mostišče, ki obsega mostarsko področje z Mostom na Soči, Modrejčanskim na desnem bregu ter Modrejanskim poljem na levem bregu Soče, na vzhodu se dvigujejo Bajnšice s Tolminskim in Kanalskim Lomom na levi strani Idrijce, na desni pa Šentviška planota. K Mostarski pokrajini spada dolina Idrijce z dolino Trebuše in Baška grapa, Voljčansko polje na levem bregu in Tolminska kotlina z dolino reke Bače in Šentviško planoto ter ozki jezik Idrijsko-Cerkljanskega hribovja, ki se stika z južnim robom Julijskih Alp nad Tolminom (glej sliko 3).

Reka Soča na Tolminsko mostišče priteče iz severozahodne smeri in spremeni smer toka ostro proti jugozahodu in steče prek Mostarskega v Kanalsko dolino.

Območje zgornje Soče obsega sotesko pri Kobaridu ter prodorno dolino reke Soče med Stolom in Polovnikom z osjo v smeri SV-JZ do kraja Žaga, kjer se smer osi doline spremeni v SV-JZ. Reka Soča prečka Bovško kotlino na njenem južnem delu med Bovško teraso in šestimi stopničastimi čezsoškimi terasami. Območje zgornje Soče sega še naprej do doline Trente, obsega celotno Bovško kotlino in vključuje dolino Učje in Koritnice.

\subsubsection{Opis območja geografske analize}

Centralni prostor analize obsega Bovško kotlino z dolino Soče do Mosta na Soči s Kaninskim podgorjem, Stolom, Matajurjem in slemeni Kolovrata, ki se dvigujejo na desnem bregu Soče; Javorščkom, Polovnikom in Krnskim pogorjem na levem bregu Soče, vključno s Kobariško in Tolminsko kotlino in z Mostarskim. Mejni prostor analize severno obsega dolino Koritnice na severovzhodu, južna pobočja Svinjaka na severu in planino Golobar na severovzhodu. Mejni prostor analize vzhodno obsega gorski masiv Krnskega pogorja in Podgorje na vzhodu stika v dolini Bače s Šentviško planoto in naprej proti JV v dolino Idrijce z Banjšico. Mejni prostor analize južno zajema območje Kanalske doline reke Soče in na levem bregu Soče planoto Banjščice s Tolminskim in Kanalskim Lomom ter na desnem bregu Kambreško (tudi Kanalsko hribovje ali Kanalski Kolovrat), ki se od Ježe v smeri zahoda prevesi v dolino Idrije, medtem ko se proti jugu razteza do Korada (nad Goriškimi brdi). Mejni

\footnotetext{
4 Za geografsko delitev in preverjanje poimenovanj posameznih lokalnih geografskih enot na Posočju je bilo pomembno delo Zorka Fona in Hinka Uršiča (1987) Dolina Soče.
} 
prostor analize zahodno obsega Kaninsko skupino, dolino Učje in vzpetine nad njo; zgornjo dolino Nadiže ter zahodna pobočja Matajurja in Kolovrata, ki se stekajo v Beneško Slovenijo in naprej v Furlanijo.

\subsubsection{Naravne enote območja in krajinske značilnosti}

Bojišče 14. armade je glede na položaj in uporabo tipoloških opredelitev regionalne razdelitve Slovenije obsegalo kar pet različnih krajinskih tipov ${ }^{5}$. Celotno zgornjesoško bojišče spada $v$ alpsko krajino. Temeljna opredelilnica makroregije je ostro podnebje ter predvsem izredna členjenost in razgibanost visokih gorskih masivov, ki jim sledijo grebeni in glavne doline. Najvišjo in najobsežnejšo alpsko krajino v Sloveniji obsega enota Julijskih Alp, v katero spadata tudi podenoti Gornja dolina Soče, ki obsega povirje in zgornjo dolino Soče z obdolinskimi gorskimi masivi, Bovško kotlino in Krnskim pogorjem, ter Zahodni Julijci, ki obsegajo skrajni zahodni rob slovenskih Alp - gorski masiv Rombona in Kanina od Predela na severu do doline Učje na jugu ter severni greben Stola. Njihova skupna značilnost so gozdna meja na okoli 1400 m nadmorske višine, s planinsko travo obrasla položnejša območja do 2000 m, bolj strma pobočja so gola in skalnata s hudourniki na obronkih in ostri grebeni na slemenih ter vrhovih, na katera se skoraj navpično dvigajo skalnate stene (pretežno apnenčaste) z melišči v podnožju. Na usekih in severnih obronkih nad $1600 \mathrm{~m}$ se vse leto zadržujejo ostanki snega. Nad $1200 \mathrm{~m}$ je teren brezvoden. Potoki in reke so izdolble globoke in ozke soteske z velikim strmcem z razširitvami, vršaji in terasami v kotlinah.

Bolj raznolik krajinski svet obsega srednje soško bojišče. Centralni del bojišča spada v krajino predalpske regije in je s krajinskimi enotami, dolino zgornje Nadiže (vključno s Kobariškim Stolom), Tolminskim in delom Idrijsko-Cerkljanskega hribovja (Šentviška planota z dolino Idrijce del zahodnoslovenskega predalpskega hribovja.

Skupne krajinske značilnosti centralnega dela bojišča so enoten srednjegorski hribovit svet, podobne nadmorske višine in oblikovanost reliefa, ki se izjemoma povzpne čez 1000 metrov, ter vlažno podnebje. Za območje so značilne globoko vrezane ozke doline z obrežnim prostorom, ki se občasno razširijo, in stranske ter globoko vrezane grape s stalnimi in občasnimi pritoki iz poraščenih hrbtov hribov in planot (značilna bogata hidrografska mreža). Planote so brez površinskih vod. Med krajinske posebnosti spadajo tudi razgaljena pobočja in izstopajoči vrhovi, celki s kmetijami, posamezni vrhovi s strnjenim gozdom ter doline s kmetijsko krajino, obdano s strnjenim gozdom in značilno razporejenimi skupinami naselij (značilni so njihov prostorski položaj, struktura in arhitektura) v razširitvah dolin - naplavinske ravnice (ob poljih $\mathrm{v}$ kotlinah na robovih doline) ter posamezne razvrednotene površine, ki so posledica posegov človeka v prostor. Zahodni del bojišča spada v subalpsko primorsko regijo (zahodni rob Banjške planote, Kambreško, zahodna

V prispevku je uporabljena tipološka opredelitev regionalne razdelitve Slovenije, ki jo je v projektu pripravilo Ministrstvo za okolje in prostor (Muršič, 1998). 
pobočja Kolovrata in Matajurja, ki se stekajo v Beneško Slovenijo). Subalpsko primorsko regijo opredeljuje podnebje, ki ima še primorski značaj, vendar z znatnimi vplivi alpskega podnebja. Razpoznavnost krajinske enote temelji na geološki zgradbi prostora in mikroreliefnih razmerah. Slemena med dolino Soče in Idrijo imajo značilen, nekoliko submediteranski videz.

Na južnem delu bojišča, do Mostarskega, sega Banjška planota, ki je z njenim dinarskim značajem (kras in razmeroma visoka nadmorska višina planote) del kraške krajine notranje Slovenije. Za Banjško planoto je značilna členjena kraška krajina na razgibanem terenu.

\subsection{Presoja zmogljivosti prostora}

Presoja zmogljivosti prostora vključuje vse vidike zemljišča in obsega analizo različnih dejavnikov, ki so povezani z okoljem bojišča. V vojaškogeografski analizi prostora $\mathrm{v}$ študiji primera tako upoštevamo identificirane prvine krajinskega vzorca, torej podnebje, relief in rabo tal ali površinski pokrov in presojamo njihovo interakcijo ter ocenimo njihove učinke na dejavnike izvajanja vojaških aktivnosti. Grafični produkt analize je sestavljena prosojnica učinkov bojišča (slika 4).

Za presojo reliefa terena nam služi pripravljen grafični sloj naklonov. Povezanost med naklonom in razgibanostjo površja je tesno povezana $\mathrm{z}$ uporabo prostora za opazovanje, ognjeno delovanje in premike. Hkrati se vpliv naklona izraža posredno v klimatskih, hidrografskih in deloma tudi pedoloških učinkih. Naklon je najpomembnejši parameter pri analizi in ocenjevanju premičnosti ter prepustnosti prostora za tehniko in ljudi. Na obravnavanem območju izstopa naklon drugega razreda (od $20.1^{\circ}$ do $40^{\circ}$ - siva barva), ki kaže območja z zelo omejeno prehodnostjo zunaj prometnic v obsegu skoraj 80 odstotkov površine. Nakloni prvega razreda (do $20^{\circ}$ ) na območju analize obsegajo nekaj več kot 14 odstotkov površine. Najobsežnejše površine z majhno razgibanostjo površja so v dolini reke Soče, dolinah nekaterih njenih pritokov in v zgornji dolini reke Nadiže. Obsežnejša območja izravnav so v Bovški, Kobariški in Tolminski kotlini. Razgiban relief z veliko gostoto izmenjujočih se površin, naklonov prvega in drugega razreda je izražen v visokogorju, na pobočnih uravnavah, podih, sedlih in v visokogorskih dolinah. Teren z nakloni med $40^{\circ}$ in $60^{\circ}$ (manj kot 5 odstotkov površine) je značilen za grebene gorskih masivov (Polovnika, Matajurja, Stola), soteske Učje ter za vrhove Idrijsko-Cerkljanskega hribovja. Najbolj ekstremne naklone, več kot $60^{\circ}$, najdemo v skalnatih stenah vrhovih gora na alpskem delu bojišča in na Matajurju.

$\mathrm{Na}$ podlagi splošne kvalifikacije reliefa lahko območje analize opredelimo kot operativno težko prehoden teren, na katerem lahko pričakujemo hitrosti premikov na ugodni smeri do $3 \mathrm{~km} / \mathrm{h}$ peš ( $7 \mathrm{~km} / \mathrm{h}$ z vozili) oziroma od 1,5 do $2 \mathrm{~km} / \mathrm{h}$ peš po manj ugodnih smereh. Na hitrost premikov vpliva tudi kategorija zemljišča (naselja, kmetijske površine, neobdelovalne površine, gozd) in struktura tal. 
Biotski dejavniki območja so prav tako posledica reliefnega dejavnika. Posegi človeka se kažejo v ustvarjanju uporabnih površin, in sicer obdelanih površin ter naselij, ki so na alpskem robu gozdno mejo potisnili navzdol, v korist planinskih trat - oblikovali so goličave in planinske pašnike.

Analiza prometne infrastrukture in poti ali stez na območju identificira zmogljivost prometne infrastrukture prostora (prikazani linijski objekti v rdeči barvi na sliki 4). Glavne komunikacije (državne ceste - debelejša črta) so speljane po dolinskem dnu Soče, Učje, Nadiže, Bače in Idrijce ter po vzhodnem delu slemena Kolovrata in Kambreškega. Mreža drugih cest in poti kaže razsežnost povezav, od kategoriziranih do nekategoriziranih poti, razdeljenih v 19 kategorij, ki so bolj ali manj dediščina zgodovine, predvsem prve svetovne vojne.

$\mathrm{Na}$ podlagi splošne kvalifikacije reliefa lahko območje analize opredelimo kot operativno težko prehoden teren, na katerem lahko pričakujemo hitrosti premikov na ugodni smeri do $3 \mathrm{~km} / \mathrm{h}$ peš ( $7 \mathrm{~km} / \mathrm{h}$ z vozili) oziroma od 1,5 do $2 \mathrm{~km} / \mathrm{h}$ peš po manj ugodnih smereh. Na hitrost premikov vpliva še kategorija zemljišča (naselja, kmetijske površine, neobdelovalne površine, gozd) in struktura tal.

Biotski dejavniki območja so prav tako posledica reliefnega dejavnika. Posegi človeka se kažejo v ustvarjanju uporabnih površin (obdelanih površin in naselij). Na alpskem robu je nemalokrat potisnil gozdno mejo navzdol v korist planinskih trat, oblikovali so se goličave in planinski pašniki.

Analiza prometne infrastrukture in poti ali stez na območju identificira zmogljivost prometne infrastrukture prostora (prikazani linijski objekti v rdeči barvi na sliki 4). Glavne komunikacije (državne ceste - debelejša črta) so speljane po dolinah Soče, Učje, Nadiže, Bače in Idrijce ter po vzhodnem delu slemena Kolovrata in Kambreškega. Mreža drugih črt prikazuje razsežnost kategoriziranih lokalnih cest in nekategoriziranih poti ${ }^{6}$, ki so dediščina zgodovine, predvsem prve svetovne vojne.

Cestno omrežje na Tolminskem in širšem soškem območju se je v novem veku, zlasti v alpskem delu, le počasi oblikovalo. Čez omenjeno območje so vse do 19. stoletja vodile slabe prometne povezave, ki so jih trasirali predvsem vojaški strokovnjaki, na primer obsoško cesto v 18. stoletju. Večinoma so trase cest potekale po ostankih rimskih cest (predelska cesta). Šele v začetku 19. stoletja je gospodarski razvoj spodbudil napredek na področju prometa. S širjenjem železniške mreže se širi tudi cestno omrežje Posočja. Gradnjo komunikacijskih povezav Posočja z notranjostjo dežele spodbudijo šele potrebe vojaštva v prvi svetovni vojni (Holz, 2013).

Z gotovostjo lahko trdimo, da gosta mreža poti in stez izhaja iz 18. stoletja, cestno omrežje pa iz 19. stoletja. Današnje trase cest so nekoliko spremenjene zaradi izbire

${ }^{6}$ Podatki so pridobljeni od Geodetske uprave RS in so v GIS MO prikazane v preglednem sloju: ceste. Na sloju so izrisane vse nekategorizirane in kategorizirane poti (19 kategorij). 
tras, ki so odmaknjene od poplavnih območij, območij skalnih podorov in snežnih plazov, in nove tehnike cestne gradnje.

Geografske usmeritve usmerjajo vojaškotaktične smeri na ozemlju Slovenije. Porečje Soče spada med tako imenovane zahodne vojaškogeografske smeri, ki jih sestavljajo primorska, kraška, vipavska, idrijska in delno gorenjska smer. Idrijska smer je vpeta v gorenjsko in vipavsko operativno vojaškogeografsko smer. Geografski prostor porečja Soče brez Bovške kotline obsega (os smeri Učja-Bača pri Modreju) in taktične objekte Matajur, Kolovrat, Kobarid, Vrsno, Tolmin in Most na Soči (Bratun, 1997).

Analiza reliefa in komunikacijske mreže na sestavljeni prosojnici učinkov bojišča izraža naslednje usmeritve prostora: predelska smer (Predel-Kobarid), gorenjska smer (Dolina Trente-Bovška kotlina-Kobarid), rezijska (Žaga-Učja), furlanijska smer (Kobarid-po dolini Nadiže-Čedad), zgornjesoška smer (Kobarid-Tolmin-Sela pri Volčah) ter škofjeloška in idrijska smer (Most na Soči v smeri notranje Slovenije).

Klimatske in hidrografske značilnosti niso enoznačne za celoten prostor. V prostoru delovanja 14. armade se srečamo z gorskim podnebjem, ki se na predelu zgornjega soškega bojišča deli na podnebje višjega gorskega sveta (značilno za predel Julijskih Alp) in podnebje nižjega gorskega sveta, ki je v Bovški kotlini izredno omiljeno zaradi vpliva zmernega sredozemskega podnebja.

Srednje soško bojišče obsega ozko območje zmernega celinskega podnebja in zmernega zalednega sredozemskega podnebja. Za območje je značilen submediteranski padavinski režim $\mathrm{z}$ viškom padavin $\mathrm{v}$ jesenskih mesecih in na prehodu pomladi $\mathrm{v}$ poletje ter $\mathrm{z}$ minimumom padavin na prehodu zime $\mathrm{v}$ pomlad in osrednjih poletnih mesecih (Gams, 1996).

Zaradi pogostih padavin $\mathrm{v}$ jesenskih (oktober in november) in spomladanskih mesecih (maj in junij) ter taljenja snega v visokogorju imajo vodotoki in reka Soča izrazit hudourniški značaj. Največja nevarnost je, ko vodotoki začnejo s tokom nositi veliko količino proda, s čimer ustvarijo drobirski tok, in se zaradi količine padavin prožijo plazovi ter nanosi različnih materialov z bregov zaradi erozijskega delovanja. Za klimatske razmere Posočja so značilne velike količine padavin s padavinskim maksimumom v Kaninskem in Krnskem pogorju ter bovški in Tolminski kotlini. Prav stik dveh različnih podnebnih tipov nad srednjim soškim bojiščem oblikuje intenzivno vremensko dogajanje (veter, orografske padavine, nevihte) in značilne lokalne pojave (megla, nizka oblačnost na pregradah ali pregretje in nastanek zaprtega kotlinskega toplotnega sistema s soparo, meglo v kotlinah in dolinah). Še posebno intenzivno vremensko dogajanje v zahodni Sloveniji je ob prodoru hladnih front do Alp. Takrat se pogosto pojavi Sredozemski ciklon, katerega kroženje povzroči močne vetrove in padavine ob južnem robu Julijskih Alp (območje maksimalnih padavin v Sloveniji). Gre za vremensko situacijo, ko mrzli zrak, ki prodre v Sredozemlje, sproži močno ciklogenezo. V bližini frontalne cone, torej meje med vlažnim, 
toplim sredozemskim in mrzlim kontinentalnim zrakom, pride do pojava izredno močnih padavin. Te so najbolj značilne prav za jesensko obdobje. Večdnevno močno deževje povzroča zbiranje vode v prsti in vodonosnikih. Dolina reke Soče kaže vse prilagoditve takim razmeram (infrastruktura in naselja). Izjemne količine padavin v Posočju padejo nekajkrat na leto ${ }^{7}$ in tedaj po gorah južnih Julijskih Alp divjajo hudourniki, trgajo se zemeljski plazovi, krušijo se skale in reka bučno hrumi ter odnaša drobir (Vrhovec, 2006, str. 57-59).

Za vojaške aktivnosti so to izredno težavne razmere in pomembno vplivajo na učinke bojišča, posebej na opazovanje in ognjeno delovanje ter premike oziroma ovire.

\section{PRESOJA UČINKOV BOJIŠČA IN VREMENA NA BOJNO DELOVANJE 14. ARMADE V 12. SOŠKI OFENZIVI}

Grafični model geografskih dejavnikov obravnavanega prostora bojev na soški fronti nam razjasnjuje značilnosti prostora za bojno delovanje. V presoji zmogljivosti prostora namenjamo večjo pozornost analizi orografskih (reliefnih) in klimatskohidrografskih dejavnikov, ki razkrivajo zahtevnost bojišča 14. armade (bojevanja v gorah), hkrati pa so oblikovali razmere za uspešno izvedbo manevra.

V prvi svetovni vojni se je na območju bojišča soške fronte zgodil obsežen destruktivni poseg v okolje. Pri pregledu fotografij območja iz časov bojev ne opazimo obsežnejših gozdnatih površin, čeprav bi jih pričakovali, če izhajamo iz današnjih razmer regeneriranega okolja. Zato v presoji zmogljivosti prostora dejavniku rastja ne namenjamo večje pozornosti, razen v obsegu analize koriščenja kritja in maske pri izbiri smeri infiltracije in izvedbi taktičnih premikov Württemberškega bataljona ${ }^{8}$.

Izraba prostora 14. armade v 12. ofenzivi je bila za tisti čas nenavadna. Nenavadna je bila $\mathrm{v}$ pogledu takratne uporabe ustaljene oblike frontalnega bojevanja. Za izvedbo ustaljenega frontalnega napada je veljalo pravilo, da lahko napadalec sproži napad pehote šele, ko bodo nasprotnika že delno uničili ali oslabili z artilerijskim ognjem. Vojaška teorija je predvidevala, da mora biti napadalec za uspešno ofenzivno delovanje vsaj dva- ali trikrat močnejši. Po pravilih gorskega bojevanja bi moral pred začetkom bitke najprej osvojiti vrhove, ki se dvigujejo nad dolinami, preden vanje vdre pehota. Nemški vojaški strokovnjaki so ocenili, da se italijanskih položajev v Julijskih Alpah ne da zavzeti. Načrtovalcem je za doseganje uspeha preostala le uporaba taktike infiltracije in ocenili so, da bi v alpskem svetu z uporabo bojnih plinov lahko dosegli uspeh (Klavora, 1993, str. 203).

Pri količini padavin nad $250 \mathrm{~mm}$ na dan.

$\&$ Ko opravljamo študijo primera, nam analiza pomaga razumeti samoobnovitveno sposobnost okolja v okviru obravnave vsebin, povezanih z varovanjem okolja, v korelaciji s temo geografski vidiki kriznih območij in območij konfliktov pri predmetu vojaška geografija. 
Na podlagi vrednotenja izrabe prostora branilca in načrta delovanja 14. armade, ki je predvideval odločilni napad po dolinah s povsem nezavarovanimi boki, lahko trdimo, da je bil koncept operacije izredno tvegan. Ofenziva bi bila $\mathrm{v}$ drugih vremenskih okoliščinah gotovo manj uspešna, če ne celo neuspešna. Sistem italijanskega zapornega ognja, ki ga skupaj z vplivi učinkov bojišča ocenjujemo glede na razporeditev italijanskih topov in potek obrambnih črt, bi neugodno vplival na doseganje ciljev 14. armade in bi verjetno preprečil prodor enot po dolini.

Izbira smeri napada po osi doline se v analizi izkaže pravzaprav kot edina mogoča smer napredovanja, ki omogoča prehodnost in premičnost enot ter zagotavlja primerno hitrost napredovanja. Smer nima alternativnih koridorjev premikov. Načrtovan in pozneje izveden prodor 14. armade je potekal po edinih mogočih geografskih smereh: Trenta/Predel-Bovška kotlina-Žaga (Predelska, Gorenjska smer), Žaga-Učja (Rezijska smer), Tolmin-Kobarid (Zgornjesoška), Kobariddolina Nadiže (Furlanijska smer).

Za uspešno izvršitev operativnega načrta je bila bistvena zasedba taktičnih objektov (najpomembnejšega zemljišča) na smereh prodora: Čukla (Prevala), Polovnik, Krn, Matajur in Kolovrat (glej sliki 1 in 2). Območja taktičnih objektov so namreč dajala ključno oporo italijanskim obrambnim položajem in zapirala (onemogočala) prodor v notranjost obrambnega območja. Koridorji premikov enot v prostoru osi doline kanalizirajo vse premike in potekajo po razvodnicah in mostovih. Zunaj doline je teren težko prehoden.

Analiza dogodkov je pokazala visoko hitrost napredovanja 14. armade. Po silovitem in hitrem preboju prve linije italijanske obrambe je steklo napredovanje po dolini, brez upočasnjevanja. Enote so se premikale po dolini v pohodnih kolonah, medtem ko so se enote v stiku na pogorju Rombona, Krna in Kolovrata bojevale (Klavora, 1994, str. 284).

Ocene prepustnosti smeri za delovanje 14. armade, tako kot jo razumemo v sodobni vojaški teoriji, ne moremo oblikovati. Identificiramo lahko le območja z večjo verjetnostjo koncentracije vojaških enot v prostoru razporeditve in ocenimo zaščitne lastnosti območja.

Zaščitne lastnosti območja koncentracije sil so bile zelo omejene in izredno tvegane. $\mathrm{Na}$ podlagi zbranih informacij o prostoru lahko $\mathrm{z}$ veliko verjetnostjo potrdimo tezo, da če bi italijanska vojska izbrala agresivnejši slog obrambe in napadla sile napadalca na območjih koncentracije sil, bi bila izvedba preboja vprašljiva. Skozi študijo razmer in obrambnih položajev lahko še opredelimo ključni teren, odločilne točke in točke odločitve.

Potrjevanje operativnih oziroma taktičnih norm na podlagi zgodovinskih razmerij sil in delovanja 14. armade je zaradi specifičnosti delovanja oteženo. 
14. armada je dosegla globino $140 \mathrm{~km} \mathrm{17}$. dan ofenzive. Ne glede na to, da je primerjava le okvirna, dosežena razsežnost dosega spodnjo mejo operativno-taktičnih norm napadne operacije armade držav članic Nata. Ta predvideva doseganje cilja v globini $150 \mathrm{~km}$ pod takimi pogoji v času 10- do 15-dnevne operacije (Grizila, 2000 str. 12).

Pri vrednotenju prostora $\mathrm{v}$ interakciji z uporabo vojaških tehnologij vrednotimo uporabo bojnih plinov. Nemške enote 14. armade so načrtovale uporabo plinskih granat in plinskih min. Glede na območje uporabe (gorska krajina) so predvidevali, da bi lahko bilo plinsko obstreljevanje gorskih hrbtov in strmih pobočij, na katerih so bile nevarne italijanske kaverne s topovi, neuspešno. Še več, upoštevali so tudi nevarnost, da bi pobočni in podolinski veter plinske hlape potisnila navzdol, v grape in doline, ter ogrozila enote (Klavora, 1993, str. 206, 207).

Izveden plinski napad v 12. ofenzivi na celotni frontni črti napada je bil uspešen le v Bovški kotlini, in to prav zaradi izbire cilja. Cilj napada so bili zakriti italijanski položaji z zakloni v globeli, ki se spušča do reke Soče in je postala plinska past ${ }^{9}$. Ustvarjen plinski oblak, ki se je zagozdil v globeli, je namreč ustvaril visoko koncentracijo smrtonosnega plina, kar je mogoče pripisati obliki terena, torej mikroreliefu, in vremenskim razmeram (brezvetrju).

Tretji pomemben geografski dejavnik, ki je bistveno vplival na uspeh 14. armade $\mathrm{v}$ 12. soški ofenzivi, so vremenske razmere $\mathrm{v}$ času priprav in preboja, ki izhajajo iz klimatskih hidrografskih značilnosti obravnavanega območja. Z vremenskimi razmerami je tesno povezana tudi izbira časa ofenzive, katere začetek je bil načrtovan za 22. oktober 2017. Načrt izvedbe ofenzive in izbira časa pred zimo leta 1917 sta bila bolj politična kot taktična odločitev. Izhajala je iz razmer na zahodni in vzhodni fronti ter ocene nevarnosti zloma avstro-ogrske vojske na Soči. Tako je prišlo 8. septembra 1917 do odločitve za operacijo (Simčič, 2006, str. 199).

Tednik Slovenski gospodar je 27. septembra 1917 poročal o velikih pripravah na 12. ofenzivo na obeh straneh Soče. Priprave in namera niso bile skrivnost, prikrita pa so ostala območja koncentracije vojaštva. Območja koncentriranja vojaštva in smeri premikov so namreč prikrivale vremenske razmere v zahodni Sloveniji, značilne za jesen. Vremenske razmere so v času priprav na ofenzivo in na začetku preboja izkazovale značilnosti obsežnega sredozemskega ciklona ${ }^{10}$. To sklepamo iz zapisov Simčiča (2006, str. 287), ki navaja, da je začelo deževati 10. oktobra.

\footnotetext{
Globel je tik pod Bovško teraso (438 m n. v.) in vodi do reke Soče (364 m n. v.), ki se zajeda v najnižjo Čezsoško teraso (369 $\mathrm{m} \mathrm{n}$. v) širine $500 \mathrm{~m}$.

10 Trajanje deževnega obdobja v zahodni Sloveniji, ki nastane ob sredozemskem ciklonu, ima svoje zakonitosti. $V$ pogovorih z domačini o vremenskih razmerah na Posočju so ti razložili lokalne vremenske razmere, ki nakazujejo razvoj vremena. Za jesenski sredozemski ciklon na Tolminskem po besedah domačina velja: če tretji dan ne neha deževati, dežuje sedem dni, in če po sedmih dneh dežja še ni konec, bo deževalo 14 dni. Pravilo sicer ni dokazano ali potrjeno, je pa leta 1917 glede na vire neprekinjeno deževalo 14 dni, od 10. do 24 oktobra.
} 
Tednik Štajerc je 4. novembra 1917 poročal o poplavah na Laškem v Italiji ${ }^{11}$ kot posledici dolgotrajnega deževja. Klavora (1994, str. 276) navaja, da je zaradi neprestanega deževja in cestnih razmer prihajalo do zamud prihodov enot na izhodiščne položaje za napad, zato je bil začetek napada 14. armade zamaknjen za dva dni, na 24. oktober.

Sneženje v visokogorju s 23. na 24. oktober 1917 je dodatno ohromilo italijansko obrambo. Napadalcem je nekaj težav na dan preboja povzročila tudi narasla Soča, ki je onemogočila uporabo nekaterih mostišč ob začetku napada ${ }^{12}$. Dan po preboju je sledila nenadna sprememba vremena - konec deževja. V noči s 24. na 25. oktober se je razjasnilo, kar je bilo v prid enotam 14. armade. Dobra vidljivost je branilcem razkrila razsežnost ofenzive in povzročila padec bojne morale (Klavora, 1994, str. 283).

Čudežna nenadna sprememba vremena je bila posledica premika ciklona nad Balkan. Prodor izredno hladnega zraka proti Jadranskemu morju je povzročil sneženje $\mathrm{v}$ visokogorju, zlitje hladne zračne mase okoli Alp pa burjo, zaradi katere se je nenadno razjasnilo.

Vremenske razmere so prispevale $\mathrm{k}$ uspešnosti izvedbe 12. soške ofenzive. Oblikovale so se razmere za uspešno pripravo ofenzive, prikrivana sta bila prihod in razporeditev enot na izhodiščne položaje. Zaradi vremena so enote pozneje prišle na izhodiščne položaje za napad, zaradi česar se je premaknil začetek napada, ob začetku ofenzive sta bila onemogočena opazovanje doline z vrhov in udejanjanje italijanskega zapornega ognja, omogočena sta bila uspešno infiltriranje jurišnih skupin in dolinski preboj enot, nazadnje pa se je zlomila bojna morala italijanskih vojakov $^{13}$. Omenjeno dejstvo bi lahko ob širši obravnavi in analizi izhoda bojevanja interpretirali s tezo, da je vreme oblikovalo zgodovino.

Sklep Analiza geografskih dejavnikov bojišča 14. armade v 12. soški ofenzivi jasno nakazuje na razmere in razloge, ki so vplivali na oblikovanje načrta operacije, ter izrazi dejavnike časa in prostora, ki so bistveno vplivali na izvajanje vojaških aktivnosti in na njihove posledice.

V članku opisani vojaškogeografski dejavniki z oceno učinkov terena in vremena na bojno delovanje neposredno potrjujejo, da so geografski dejavniki zgornjega in srednjega soškega bojišča določali in usmerjali aktivnosti 14. armade v 12. soški ofenzivi: opredeljevali so območja zbiranja in koncentracije sil ter cilje in smeri

\footnotetext{
II V novembrskem Štajercu so novice opisovale dogajanja in posledice deževja iz druge polovice oktobra. Visti številki Štajerc poroča tudi o uspehih 12. ofenzive in povzema poročila Dunaja od 25. oktobra naprej. O posledicah vremenskega dogajanja dramatično poroča: „Oblak se je utrgal in popolnoma preplavil mesta in polja. Ceste in železnice v vzhodni in zahodni smeri so pretrgane in na stotine hiš je porušenih."

12 Zaradi visoke Soče so na položajih za naskok ostale enote pri vasi Dolje in pod Kozlovim robom pri Tolminu. Dva bataljona pa so morali premestiti na severni del mostišča čez most južno od Tolmina (Klavora, 1994, str. 283).

13 12. soško ofenzivo bi lahko primerjali z najbolj znanimi dogodki v zgodovini, ki jih opisuje Durschmied (2001), ko so vremenski pojavi posegli v izid bitke, vojaške dejavnosti ali celo revolucije.
} 
delovanja enot. Geografski dejavniki bojišča so omogočili uspešno uporabo takrat še neuveljavljene taktike bojevanja in bistveno pripomogli k uspehu 12. soške ofenzive.

Vrednotenje vremena $v$ času priprav in ob izvedbi preboja na tolminskem mostišču je bistveno za razumevanje vpliva vremena na izvajanje bojnih delovanj in uspešne realizacije načrta 12 . ofenzive.

S pomočjo študije primera delovanja 14. armade v 12. soški ofenzivi spoznavamo vojaško delovanje na specifičnem zemljišču in v značilnih razmerah, ki ga izražajo zemljepisne značilnosti bojišča ter potrjujejo in utrjujejo usvojena teoretična spoznanja vojaških ved vojaške geografije in taktike. Čeprav pri izvajanju zgodovinske študije primera v celoti ne uporabljamo modela geografskih dejavnikov obravnavanega prostora iz obdobja bojev na soški fronti, nam spoznavanje prostora in njegovih krajinskih značilnosti razjasnjuje ter odslikava vso težavnost načrtovanja uporabe prostora za bojno delovanje.

Geografska analiza prostora nam posredno odkrije geografske dejavnike, ki so vplivali tudi na načrtovanje in izvedbo 12. soške ofenzive, ter izrazi pomembnost zemljišča - Tolminskega mostišča, kjer je prišlo do uspešnega preboja.

1. Bratun, Z., 1997. Geografski dejavniki državnovarnostnega sistema RS. Doktorska disertacija. Ljubljana: Oddelek za geografijo FDV.

2. Bratun, Z., 2000. Geografija v vojaškem šolstvu. V Bratun, Zvonimir ur. Vojaška geografija v Sloveniji. Ljubljana: MORS in Oddelek za geografijo Filozofske fakultete v Ljubljani, 2000, str. 13-23.

3. Bratun, Z., 2005. Vojaška geografija I. Ljubljana: Fakulteta za družbene vede.

4. Conduct of the Staff Ride. Developed by Tactics Division, Amphibious Warfare School. htps://www.nps.gov/ande/planyourvisit/upload/Conductofthestaffride.pdf, 7. 7. 2016.

5. Durschmied, E., 2001. The Weather Factor: how nature has changed history. New York: ArcadePublishing.

6. Fabčič, D., in Rožanec, J., 1999. Obveščevalna priprav bojišča-gradivo tečaja. Pokljuka: GŠSV.

7. Fon, Zorko in Uršič, H., 1987. Dolina Soče. Ljubljana: DZS.

8. Galič, Marušič, 2005. Tolminsko mostišče I. Tolmin: Tolminski muzej.

9. Gams, I., 1996. Geografija Slovenije. Ljubljana: Mladinska knjiga.

10. Grizila, B., 2001. Priročnik za podporo vojaškega preigravanja. Ljubljana: GŠSV.

11. Holz, E., 2013. Cestno omrežje na Tolminskem v novem veku. V Kafol, ur. Tolminska v času punta: zbornik ob 300-letnici tolminskega punta. Tolmin: Tolminski muzej, 2013, str. 33-57.

12. Klavora, V., 1993. Plavi Križ. Koper: Založba Lipa.

13. Klavora, V.,1994. Koraki skozi meglo. Celovec, Ljubljana, Dunaj: Mohorjeva družba.

14. Kunaver, J., 2000. Vojaška geografija v Sloveniji, med preteklostjo in prihodnostjo. V Bratun, Zvonimir, 2000. Geografija v vojaškem šolstvu. V Bratun, Zvonimir ur. Vojaška geografija v Sloveniji. Ljubljana: MO in Oddelek za geografijo Filozofske fakultete $v$ Ljubljani, 2000, str. 25-32. 
15. Mesec, B., 1998. Študija primera v socialnem delu (̌̌tudijsko gradivo). https://sites. google.com/site/kvalitativnametodologija/kvalitativna-metodologija/studija-primera, 15. 10. 2016.

16. Muršič, J., Ogrin, D., in Jančič, M., s sodelavci, 1998. Projekt: Regionalna razdelitev krajinskih tipov Slovenije - v zbirki: Metodološke osnove; 1 Krajine alpske regije; 2 Krajine predalpske regije; 3 Krajine subpanonske regije; 4 Kraške krajine notranje Slovenije; 5 Krajine primorske regije. Ljubljana: Ministrstvo za okolje in prostor Republike Slovenije; Urad RS za prostorsko planiranje.

17. Simčič, M., 2006. 888 dni bojev na Soči: spopadi na krasu in Visokogorju na fotografijah, na novo odkritih zemljevidih in v posebnih poročilih. Ljubljana: Orbis.

18. Slovenski gospodar, št. 39, 1917. https://dlib.si/, 5. 9. 2017.

19. Starman, A. B., 2013. Studija primera kot vrsta kvalitativne raziskave. Sodobna pedagogika 1/2013. http://www.dlib.si/results/?=\&query=\%27rele\%253dSodobna\%2bpe dagogika\%27\&pageSize $=25 \&$ fyear $=2013,10.10 .2016$.

20. Štainer, A., 2000. Prenos obvě̌čevalne priprave bojišča v delo poveljstev Slovenske vojske in njena geoinformacijska podpora. V Bratun, Zvonimir, 2000. Geografija v vojaškem šolstvu. V Bratun, Zvonimir ur. Vojaška geografija v Sloveniji. Ljubljana: MORS in Oddelek za geografijo Filozofske fakultete v Ljubljani, 2000, str. 96-111.

21. Štajerc, št. 44, 1917. https://dlib.si/, 5. 9. 2017.

22. Varanneli, L., 2016. Vzročna zveza in naključje. Ljubljana: Litteralis.

23. Vrhovec, T., Kastelec, Damijan in Petkovšek, Zdravko, 2006. Vreme in podnebje v gorah. Ljubljana: Tehniška založba Slovenije.

24. Vojaška karta 5550-obrambni položaji italijanskih sil dne 17. 5. 1917. HUNGARICANA: website of Hungarian archives_Institute and Museum of Military History. ttps:// maps.hungaricana.hu/en/HTITerkeptar/5550/view/?pg =1\&bbox=-3300\%2C9089\%2C13339\%2C-97, 5. 9. 2017.

25. Vojaška karta 5551 Tolmein z vrisano situacijo vojaških položajev dan 18. 9. 1917. HUNGARICANA: website of Hungarian archives_Institute and Museum of Military History. https://maps.hungaricana.hu/en/HTITerkeptar/5891/view/?bbox $=-3325 \% 2 \mathrm{C}$ $5570 \% 2 C 10355 \% 2 C-225,5.9 .2017$. 
Slika $1:$ Shematski prikaz razporeda in načrt delovanja I. avstro-ogrskega korpusa

14. armade $v$ 12. soški ofenzivi (lasten prikaz)

Figure 1:

Outline of

the force distribution and operational plan of the Ist Austro-

Hungarian

Corps of the $14^{\text {th }}$ Army in the Twelfth Isonzo Offensive

(author's own outline) ${ }^{1}$

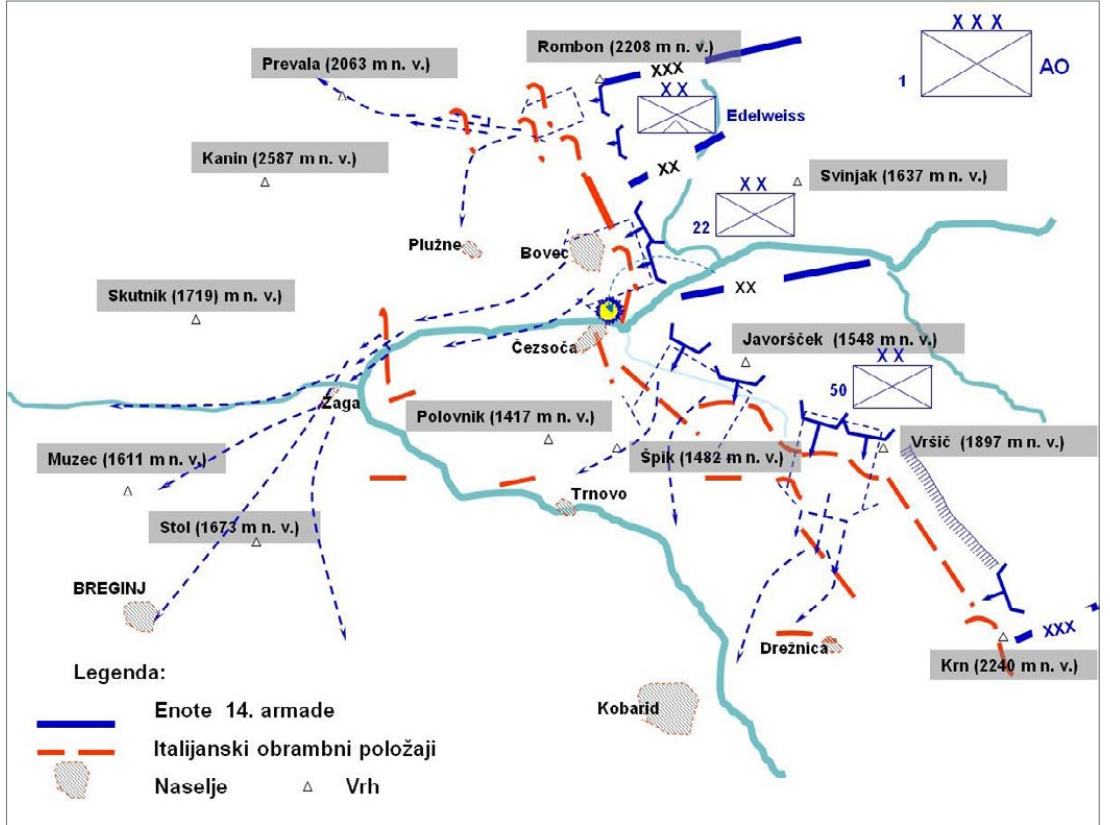

Shema delovanja na sliki je narejena po predlogi vojaške karte 5550 - obrambni položaji italijanskih sil dne 17. 5. 1917. Operational outline in the figure is based on the military map 5550 - defence positions of Italian forces on 17 May 1917.
Slika 2:

Shematski prikaz razporeda in načrt delovanja ofenzivnih enot 14. armade $v$

12. soški ofenzivi ob srednjem toku Soče $(\text { lasten prikaz) })^{2}$

Figure 2: Outline of the force distribution and operational plan of offensive units of the $14^{\text {th }}$

Army in the

Twelfth Isonzo Offensive down the midstream of the Isonzo River. (author's own outline) $)^{2}$

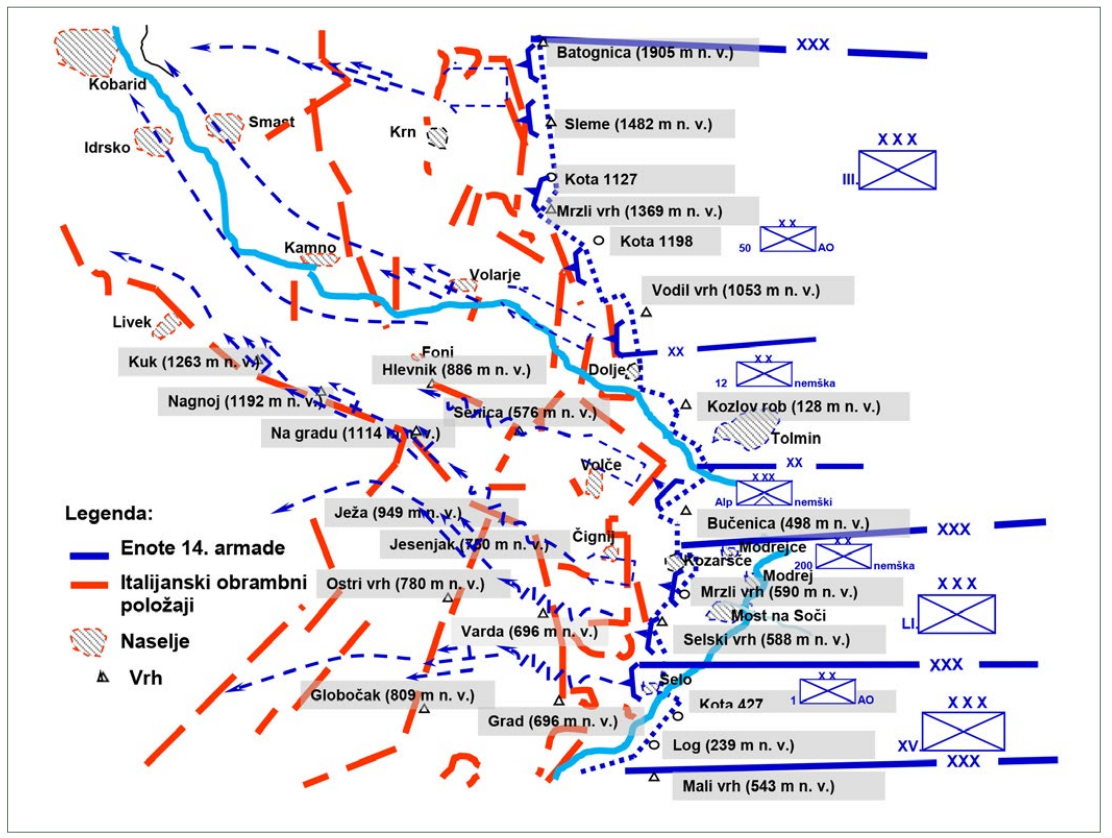

Shema na sliki 2 je narejena po predlogi situacije na dan 18. 9. 1917, izrisani na vojaški karti 5551 Tolmein. Outline in figure 2 is based on the situation on 18 September 1917 depicted in the military map 5551 Tolmein 
Slika 3:

Regionalna raz-

delitev krajinskih

tipov z oprede-

litvijo Tolmin-

skega mostišča

na bojišču 14

armade 1917

$(\text { lasten prikaz) })^{3}$

Figure 3:

Regional

classification of

landscape types

with the outline

of the Tolmin

bridgehead in

the $14^{\text {th }}$ Army

battlefield in

1917.

(author's own

outline) ${ }^{3}$

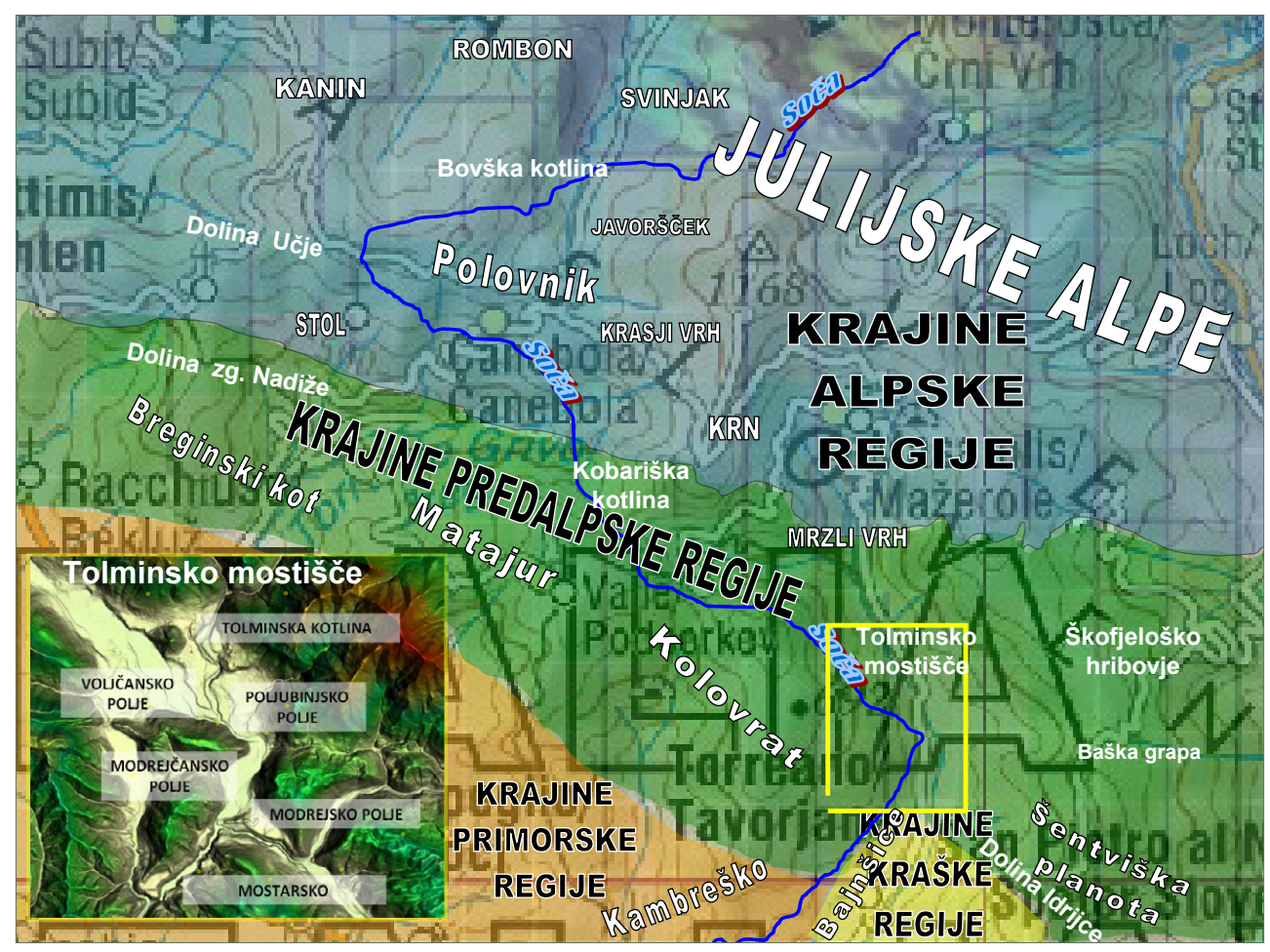

Slika je narejena na podlagi izbranega izseka iz topografske karte v UDiGISP pregledovalniku prostorskih podatkov - UTM33 MORS - Služba za informatiko in komunikacije, 3. 9. 2017, in temelji na regionalni razdelitvi krajinskih tipov v Sloveniji, MOP RS Muršič (1998).

The figure is based on a selected section from a topographic map in the UDiGISP browser of spatial dataUTM33 MORS - Information and Communications Service, 3 September 2017 and is derived from the regional classification of landscape types in Slovenia, MOP RS Muršič (1998) 
Slika 4a:

Sestavljena

prosojnica

učinkov bojišča

(brez sloja

vegetacije).

$\checkmark$ programu

ARCGIS izdelal

Vido Blažič,

SV MO 2017.

Figure 4a:

Combined

overlay

representing

battlefield

effects

(no vegetation

layer).

Made by Vido

Blažič, SAF/

MoD 2017

with ARCGIS

software.

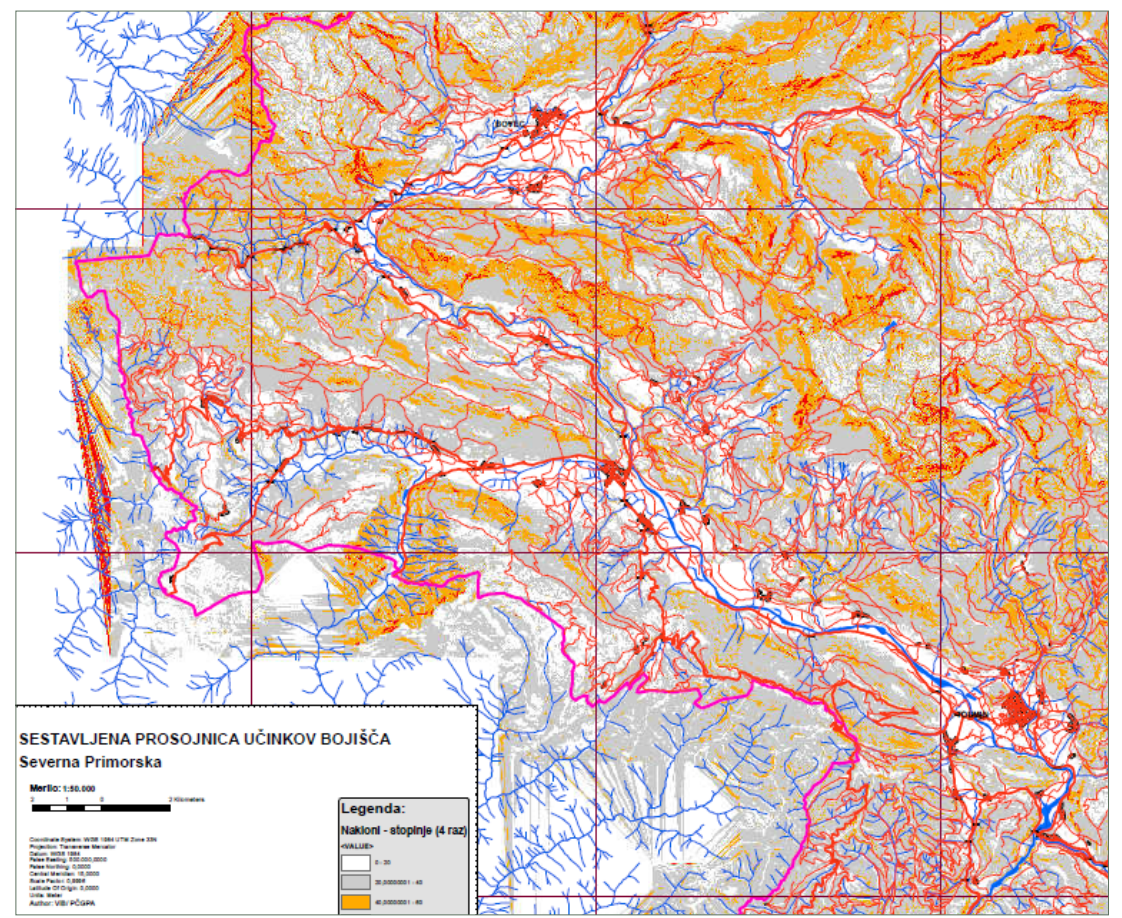

Slika 4b:

Sestavljena

prosojnica

učinkov bojišča

(s slojem

vegetacije).

$\checkmark$ programu

ARCGIS izdelal

Vido Blažič, SV

MO 2017.

Figure 4b:

Combined

overlay

representing

battlefield

effects

(vegetation layer

included).

Made by Vido

Blažič, SAF/

MoD 2017

with ARCGIS

software.

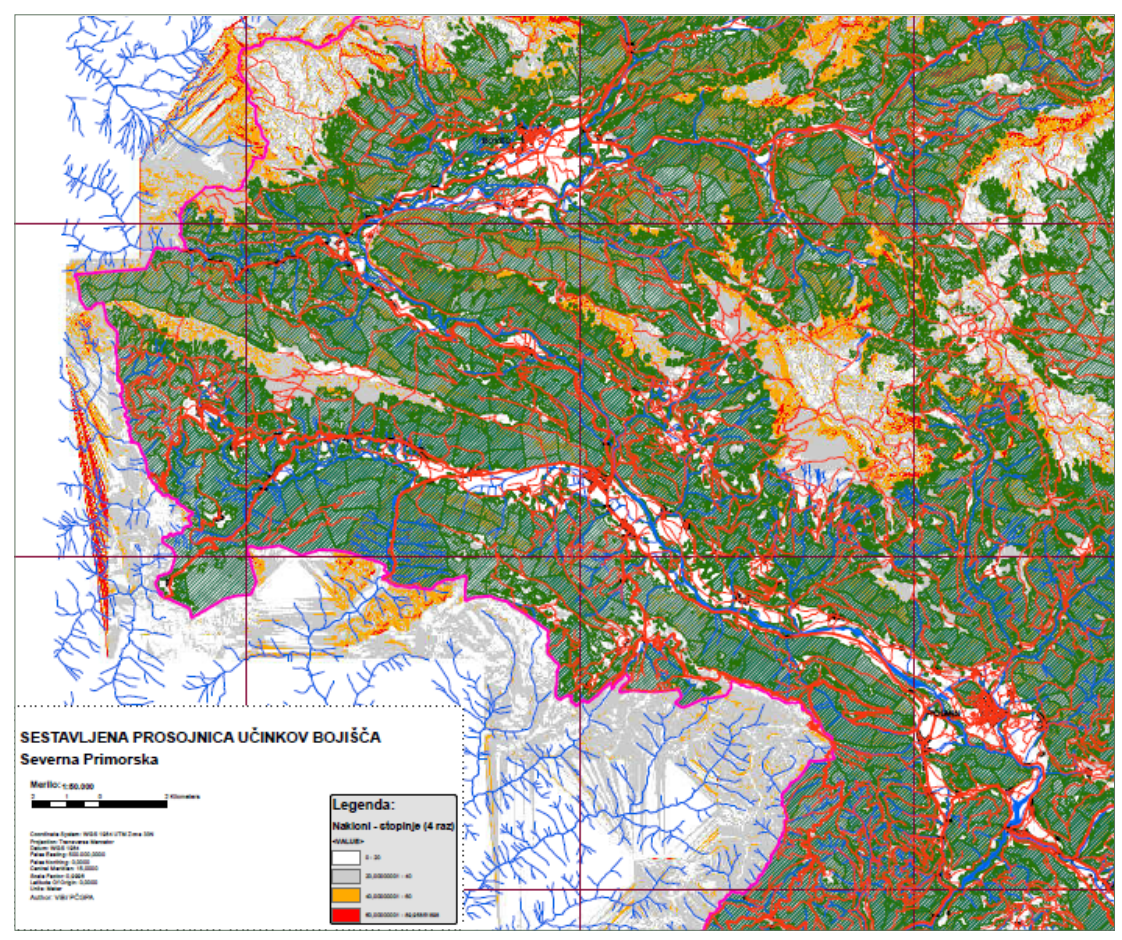

